\title{
Adherence of Burkholderia cepacia to respiratory tract epithelial cells and inhibition with dextrans
}

\author{
Cheng-Hsun Chiu, ${ }^{1}$ Simon Wong, ${ }^{2}$ Robert E. W. Hancock ${ }^{3}$ \\ and David P. Speert ${ }^{4}$
}

Author for correspondence: David P. Speert. Tel: +1 604875 2438. Fax: +1 6048752226.

e-mail: speert@interchange.ubc.ca

\footnotetext{
1 Department of Paediatrics, Chang Gung Children's Hospital, Kweishan 333, Taoyuan, Taiwan

2 The Edward Jenner Institute for Vaccine Research, Compton, Newbury, Berkshire, UK

3,4 Department of Microbiology and Immunology ${ }^{3}$, and Department of Paediatrics ${ }^{4}$, University of British Columbia, Vancouver, British Columbia, Canada
}

\begin{abstract}
Adherence of Burkholderia cepacia to cells of the respiratory tract of patients with cystic fibrosis (CF) appears to be a necessary precondition for colonization and infection. To date, no effective anti-adhesive strategy has been devised for preventing $B$. cepacia infection in CF patients. It was found in this study that $B$. cepacia adhered to respiratory epithelial cells both in vitro and in vivo. However, strains with cable-like pili (Cbl) exhibited the typical clump formation on pneumocytes, whereas non-cable piliated strains predominantly showed single-cell adherence. Dextrans (nominally 4000-10000 Da) significantly inhibited adhesion of B. cepacia to A549 pneumocytes. When compared on an equal weight basis, the nominally 10000 Da dextran was most inhibitory. A dose-dependent inhibitory effect (up to $80 \mathrm{mg} \mathrm{ml}^{-1}$ ) was observed for most strains. Dextran exerted less of an anti-adhesive effect on the two $\mathrm{Cbl}^{+}$strains than on the others which were $\mathrm{Cbl}^{-}$. Dextrans appeared to block the adherence in a non-specific fashion, as shown by the observations that the inhibitory effect was readily reversible and oligosaccharides composed of 2-4 glucose units with the same $\alpha-1,6$ linkage were not inhibitory. The mean molecular masses of dextrans used in this study, as determined by gel filtration and MS, were approximately 10 -fold lower than those indicated by the manufacturers. Our data suggest that dextran of nominal molecular mass $4000 \mathrm{Da}$ at a concentration of $40 \mathrm{mg} \mathrm{ml}^{-1}$ (10 mM according to manufacturer's quoted molecular mass) or more may be useful in patients with CF to prevent colonization and infection with $B$. cepacia.
\end{abstract}

Keyword: cystic fibrosis

\section{INTRODUCTION}

Burkholderia cepacia is commonly found in soil and water and on plant surfaces. Its ubiquity in nature may contribute to its emergence as an opportunistic pathogen of humans, particularly those with cystic fibrosis (CF) (Isles et al., 1984; Tablan et al., 1985; Canadian cystic fibrosis foundation medical/scientific advisory committee, 1993). The clinical outcome for colonized CF patients is variable, but in about $30 \%$ of these patients, the clinical course is rapidly fatal, usually within a few months following acquisition of the organism (Isles et al., 1984; Tablan et al., 1985). Furthermore, in CF

Abbreviation: $\mathrm{CF}$, cystic fibrosis. patients who undergo lung transplantation, infection with $B$. cepacia enhances mortality by approximately fivefold (Snell et al., 1993).

Recent taxonomic studies of isolates from human (CF and non-CF) and environmental origin indicate that the species B. cepacia is, in fact, highly heterogeneous, being composed of many subgroups, some of which might be reclassified as separate species (Govan et al., 1996; Vandamme et al., 1997). There are at least five distinct genotypic species in B. cepacia, referred to as genomovars I-V (Govan et al., 1996; Vandamme et al., 1997). All five genomovars have been isolated from CF patients; most of the epidemic strains are from genomovar III (Vandamme et al., 1997).

Despite the progress in taxonomy and a better under- 
standing of its evolving role in pulmonary infection in patients with CF, very little is known about the properties of $B$. cepacia that contribute to pulmonary infection. One of the most important microbial factors facilitating colonization and infection may be adhesion to host tissues, which seems to be mediated by bacterial pili (Kuehn et al., 1992; Goldstein et al., 1995). Recent molecular studies have confirmed at least five different structural pilus types in different $B$. cepacia strains; one pilus type has been implicated in the enhanced transmissibility of one clone of B. cepacia (Goldstein et al., 1995). This unique clone, expressing the specific cablelike pilus $(\mathrm{Cbl})$, has been recovered from CF patients in Canada and Great Britain, many of whom have rapidly deteriorated. This clone exhibits specific in vitro binding with high affinity to carbohydrates of respiratory mucins (Sajjan \& Forstner, 1992); the mucin-binding adhesin is a $22 \mathrm{kDa}$ protein present on the pili (Sajjan \& Forstner, 1993; Goldstein et al., 1995). This Cbl pilus is the only genetically well characterized putative virulence factor associated with an epidemic B. cepacia strain type (Sajjan \& Forstner, 1992, 1993; Sajjan et al., 1995). Whereas another genetic element, the B. cepacia Epidemic Strain Marker (BCESM), is also associated with epidemic spread among patients with $\mathrm{CF}$, its mechanism of action remains unexplained (Mahenthiralingam et al., 1997).

B. cepacia appears to establish colonization by adhering first to respiratory tract epithelial cells (Kuehn et al., 1992). Once colonization with this pathogen is established, however, it is rarely if ever eradicated. Attempts to prevent bacterial colonization and infection in patients with CF by administering prophylactic antibiotics have been unsuccessful (Speert, 1989). A potential explanation is that epidemic B. cepacia strains have adapted to the role of human intracellular pathogen with the ability to invade and survive within respiratory epithelial cells (Burns et al., 1996) and professional phagocytes (Saini et al., 1999). This virulence phenotype could conceivably protect them from actions of extracellular antibiotics. Since infection of CF patients with $B$. cepacia is associated with an adverse prognosis, a novel strategy for preventing respiratory tract colonization is urgently needed.

Dextrans are $\alpha-1,6$-linked homopolymers of glucose that have been used clinically as plasma volume expanders and antithrombotic agents. In previous studies, we have found that dextrans inhibit the adherence of $P$. aeruginosa to A549 pulmonary epithelial cells (Barghouthi et al., 1996) and prevent infection in neonatal mice when administered by aerosol (Bryan et al., 1999). We reasoned that these agents might also interfere with the adherence of B. cepacia to epithelial cells. The present study was undertaken to evaluate the capacity of dextrans to inhibit the binding of B. cepacia to A549 pneumocytes. We also explored the characteristics of binding of selected $\mathrm{Cbl}^{+}$and $\mathrm{Cbl}^{-}$B. cepacia strains in vitro to A549 cells and in vivo to murine respiratory tract epithelial cells to further elucidate the role for the cable-like pili in bacterial adherence.

\section{METHODS}

Bacterial strains and growth conditions. The description of strains used in this study is given in Table 1 . All B. cepacia isolates recovered from patients with CF, patients without CF and the environment were received from the contributors acknowledged previously (Mahenthiralingham et al., 1996, 1997). Culture and confirmation of identification of isolates were carried out as described previously (Mahenthiralingham et al., 1996, 1997). B. cepacia was grown statically at $37^{\circ} \mathrm{C}$ in Luria broth (L broth) overnight. Before use in the adherence assay, the unwashed bacterial suspension was diluted with $\mathrm{L}$ broth to an $\mathrm{OD}_{600}$ of 0.5 (Spectronic 2000; Bausch and Lomb).

Cell culture. The A549 pneumocyte cell line (CCL165) was obtained from the American Type Culture Collection (ATCC; Manassas, VA, USA). The cells were grown to confluence in $25 \mathrm{~cm}^{2}$ tissue culture flasks (Falcon), removed after treatment with $1 \times$ trypsin/EDTA $(0 \cdot 25 \%$ Trypsin, $1 \mathrm{mM} \mathrm{EDTA.4Na})$ (Gibco BRL), enumerated and plated at $5 \times 10^{4}$ cells per acidwashed, $12 \mathrm{~mm}$ coverslip and incubated overnight in F-12K medium (Gibco BRL) supplemented with $10 \%$ fetal calf serum (FCS) before use in the adherence assay.

Adherence assay. Adherent cells were washed twice with warm PBS ( $\mathrm{pH} 7.4$ ) and incubated for $30 \mathrm{~min}$ in $0.5 \mathrm{ml}$ binding buffer $\left(138 \mathrm{mM} \mathrm{NaCl}, 8 \cdot 1 \mathrm{mM} \mathrm{Na} \mathrm{HPO}_{4}, 1.5 \mathrm{mM} \mathrm{KH}_{2} \mathrm{PO}_{4}\right.$, $2.7 \mathrm{mM} \mathrm{KCl}, 1 \mathrm{mM} \mathrm{MgCl}, 0.25 \mathrm{mM} \mathrm{CaCl} 2$ and $0.001 \%$ phenol red, $\mathrm{pH} 7 \cdot 4$ ) with or without dextran or another binding inhibitor. An aliquot of $25 \mu \mathrm{l}$ of bacterial suspension $\left(\mathrm{OD}_{600}=0.5\right)$ in $\mathrm{L}$ broth was then added and incubation was continued for $40 \mathrm{~min}$ at $37^{\circ} \mathrm{C}$. The coverslips were then washed four times with warm PBS and fixed with methanol for at least $15 \mathrm{~min}$. The coverslips were mounted on slides, stained with fresh $3 \%$ Giemsa stain for $15 \mathrm{~min}$ and examined microscopically. If bacteria showed clump formation on the surface of the epithelial cells when they bound, each clump was counted as one bacterium. Approximately 50 cells per coverslip were examined to calculate the number of adherent bacteria per epithelial cell. Data were expressed as mean number of bound bacteria per cell \pm sEM. All experiments were done at least three times in duplicate.

Immunohistological staining. To characterize the adherence patterns of various B. cepacia strains to A549 pneumocytes, the following was done. After completion of the adhesion assay, as described above, coverslips were washed with PBS and incubated with polyclonal rabbit antiserum to B. cepacia strain JTC (dilution of $1: 5000$ ) at $25^{\circ} \mathrm{C}$ for $0.5 \mathrm{~h}$. Slides were then washed and incubated with biotinylated goat anti-rabbit IgG, followed by the avidin-biotin complex (Signet Laboratories). Finally, the substrate diaminobenzidine was applied and the specimens counterstained with haematoxylin. Sections were covered with aqueous mountant and dried on a warming plate at $60^{\circ} \mathrm{C}$ until the mountant was polymerized. Slides were then examined by light microscopy.

Mice. Female C57BL/6 mice were purchased from Charles River Breeding Laboratories, St-Constant, Quebec, Canada. Mice were maintained in a specific pathogen-free environment until challenge with $B$. cepacia, after which they were housed in a biohazard room. Mice were used between 6 and 8 weeks of age. The animal procedures were approved by the University of British Columbia Committee on Animal Care, Vancouver, BC, Canada.

In vivo adherence. Bacterial inocula were prepared by seeding five colonies of each B. cepacia strain to $5 \mathrm{ml}$ Luria broth (L broth) and allowing them to grow for $18 \mathrm{~h}$ at $37^{\circ} \mathrm{C}$. Bacteria were collected by centrifugation and resuspended in $1 \mathrm{ml} 1 \%$ 
Table 1. B. cepacia strains used in this study

\begin{tabular}{|c|c|c|c|c|}
\hline Strain & Genomovar & Description* & $\operatorname{cblA} \uparrow$ & BCESM $\dagger$ \\
\hline Cep31 & I & ATCC 25416, environmental strain & - & - \\
\hline Cep509 & I & $\mathrm{CF}$ isolate, non-epidemic & - & - \\
\hline JTC & II (B. multivorans) & CGD isolate & - & - \\
\hline Cep54 & III & CF epidemic strain & - & + \\
\hline C1257 & III & CF epidemic strain & - & + \\
\hline C4455 & III & CF epidemic strain & - & + \\
\hline C6433 & III & CF epidemic strain & - & + \\
\hline C5424 & III & CF epidemic strain & + & + \\
\hline BC7 & III & CF epidemic strain & + & + \\
\hline Cep40 & $\mathrm{V}$ (B. vietnamiensis) & CF isolate, non-epidemic & - & - \\
\hline $\mathrm{C} 2822$ & $\mathrm{~V}$ (B. vietnamiensis) & CF isolate, non-epidemic & - & - \\
\hline
\end{tabular}

* CGD, Chronic granulomatous disease.

† Presence or absence of the cable pilus gene, $c b l A$, and the B. cepacia Epidemic Strain Marker (BCESM) was determined by a dot-blot hybridization assay using specific DNA probes (Mahenthiralingham $e t$ al., 1997). +, Present; -, absent.

gelatin-Hank's balanced salt solution (gel-HBSS; Gibco BRL). All mice were challenged intratracheally with approximately $5 \times 10^{8}$ bacteria in $50 \mu \mathrm{l}$ gel-HBSS and sacrificed by cervical dislocation $1 \mathrm{~h}$ after the infection. Immunohistologically stained lung sections were examined microscopically for bacterial adherence.

Dextrans and oligosaccharides. Dextrans of nominal molecular mass 4000 and $6000 \mathrm{Da}$ were provided by Polydex Pharmaceuticals. Dextran of nominal molecular mass $10000 \mathrm{Da}$ and three oligosaccharides, including isomaltose $(\mathrm{Glc} \alpha 1 \rightarrow 6 \mathrm{Glc})$, isomaltotriose (Glc $\alpha 1 \rightarrow 6 \mathrm{Glc} \alpha 1 \rightarrow 6 \mathrm{Glc})$ and isomaltotetraose $\left[(\mathrm{Glc} \alpha 1 \rightarrow 6 \mathrm{Glc})_{3} \mathrm{Glc}\right]$, were obtained from Sigma.

Gel filtration of dextrans. Dextran mixtures of each nominal molecular mass were separated first according to size by gel filtration chromatography using Bio-Gel P4 (Bio-Rad). Conditions were essentially as described by Ashford et al. (1987). Several milligrams of material was loaded on to a $1.5 \times 100 \mathrm{~cm}$ column. The solvent used was water. The eluant was monitored by changes in refractive index, the eluted fractions were combined into several pools and small amounts of these pools were analysed further by HPLC and MS.

HPLC and MS analysis of dextrans. Small samples from each pool were fluorescently labelled by reductive amination with 2-aminobenzamide, according to the method of Bigge et al. (1995), using a Signal Labelling Kit (Oxford GlycoSciences). HPLC analysis was then performed by procedures described by Guile et al. (1996) using a Waters 2690XE separations module and a Jasco FP-920 fluorescence detector. The mixtures of labelled dextran oligomers were separated by normal phase HPLC on a $4.6 \times 250 \mathrm{~mm}$ Oxford GlycoSciences Glycosep-N column. A binary gradient system using $50 \mathrm{mM}$ ammonium formate, $\mathrm{pH} 4 \cdot 4$ (solvent A), and acetonitrile (solvent B) was used. Initial conditions of $35 \%$ solvent $\mathrm{A}$ and a flow rate of $0.4 \mathrm{ml} \mathrm{min}^{-1}$ were followed by a linear gradient of $35-58 \%$ solvent A over the next $92 \mathrm{~min}$. The flow rate was then increased to $1 \mathrm{ml} \mathrm{m^{-1 }}$ over the next $2 \mathrm{~min}$ and the column washed in $100 \%$ solvent $\mathrm{A}$ for $5 \mathrm{~min}$ before being reequilibrated in $35 \%$ solvent $\mathrm{A}$ for the next injection. Column temperature was maintained at $30{ }^{\circ} \mathrm{C}$ and total run time between samples was $120 \mathrm{~min}$. The eluant was monitored by fluorescence (excitation at $330 \mathrm{~nm}$, emission at $420 \mathrm{~nm}$ ).

Matrix-assisted laser desorption/ionization MS was performed using a PerSeptive Biosystems Voyager elite reflection spectrometer as described by Kuster et al. (1997). Samples were loaded on to the mass spectrometer target in $1 \mu \mathrm{l}$ water, mixed with $1 \mu \mathrm{l}$ 2,5-dihydroxybenzoic acid $\left(10 \mathrm{mg} \mathrm{ml}^{-1}\right.$ in acetonitrile) and allowed to dry. Oligosaccharides were observed as $[\mathrm{M}+\mathrm{Na}]^{+}$ions accompanied by a smaller signal of the respective $[\mathrm{M}+\mathrm{K}]^{+}$ions in the positive ion spectra.

\section{RESULTS}

\section{Adherence of $B$. cepacia to respiratory tract epithelial cells in vitro and in vivo}

B. cepacia strains showed different, but efficient levels of binding to A549 pneumocytes. $\mathrm{Cbl}^{+}$B. cepacia strains C5424 and BC7 exhibited clump formation when they were bound to A549 cells. Immunoperoxidase staining confirmed this specific binding pattern associated with $\mathrm{Cbl}$; in contrast, $\mathrm{Cbl}^{-}$strains predominantly showed single-cell binding (Fig. 1). After intratracheal inoculation with approximately $5 \times 10^{8}$ bacteria, either $\mathrm{Cbl}^{-}$ (strain C6433) or $\mathrm{Cbl}^{+}$(strain C5424) B. cepacia adhered to murine respiratory epithelial cells. Fig. 2 shows a representative in vivo adherence assay of B. cepacia. By the use of immunoperoxidase staining, $B$. cepacia diffusely attached to alveolar septa $1 \mathrm{~h}$ after infection; C5424 demonstrated the typical clump formation, while C6433 adhered to the epithelial cells individually.

\section{Inhibition by dextran of $B$. cepacia adherence to respiratory tract epithelial cells}

Dextran (nominally $4000 \mathrm{Da}$ ) at a concentration of $20 \mathrm{mg} \mathrm{ml}^{-1}$ inhibited adhesion of all B. cepacia strains of 

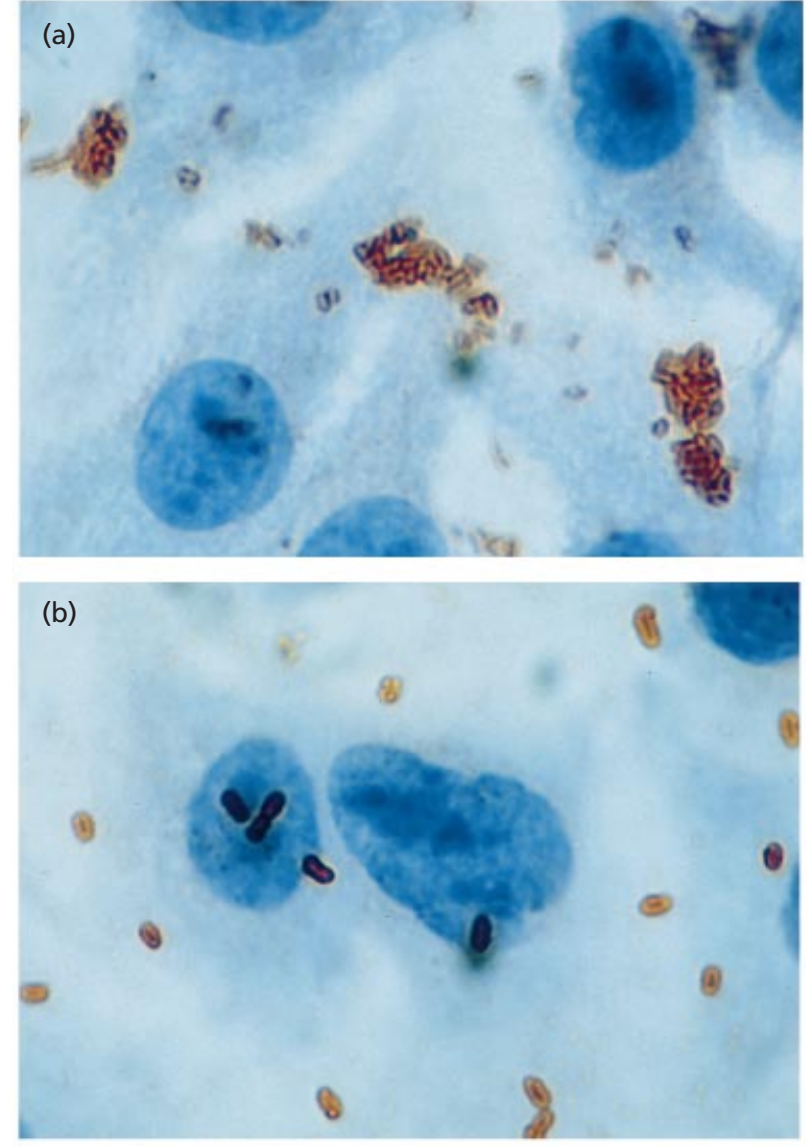

Fig. 1. In vitro adherence of $\mathrm{Cbl}^{+}$and $\mathrm{Cbl}^{-}$B. cepacia to $\mathrm{A} 549$ pneumocytes. B. cepacia were bound to A549 pneumocytes and visualized by immunoperoxidase staining as described in Methods. $\mathrm{Cbl}^{+} \mathrm{C} 5424$ (a) shows clump formation, whereas $\mathrm{Cbl}^{-}$strain $\mathrm{C6433}$ (b) predominantly exhibits single bacteria adhering.

different genomovars to A549 pneumocytes. A dosedependent inhibitory effect (up to $80 \mathrm{mg} \mathrm{ml}^{-1}$ ) was observed for most strains (Fig. 3). Dextran exerted less of an anti-adhesive effect on the two $\mathrm{Cbl}^{+}$strains $(\mathrm{BC} 7$ and C5424) than on the others which were all Cbl ${ }^{-}$(Fig. 3). Nonetheless, profound inhibition of adherence was observed for all strains by dextran at a concentration of $\geqslant 40 \mathrm{mg} \mathrm{ml}^{-1}$. The photomicrographs in Fig. 4 demonstrate the effect of dextran on $\mathrm{Cbl}^{+}$and $\mathrm{Cbl}^{-}$strains. B. cepacia also showed some non-specific binding to the glass coverslips, a phenomenon which was also inhibited by dextran. Adhesion was suppressed by all molecular mass preparations tested, but when they were compared on an equimolar basis, the nominally $10000 \mathrm{Da}$ dextran was the most inhibitory (Fig. 5).

\section{Reversible anti-adhesive effect of dextran}

If the A549 pneumocytes were pretreated with dextran and then washed with PBS before adding bacteria
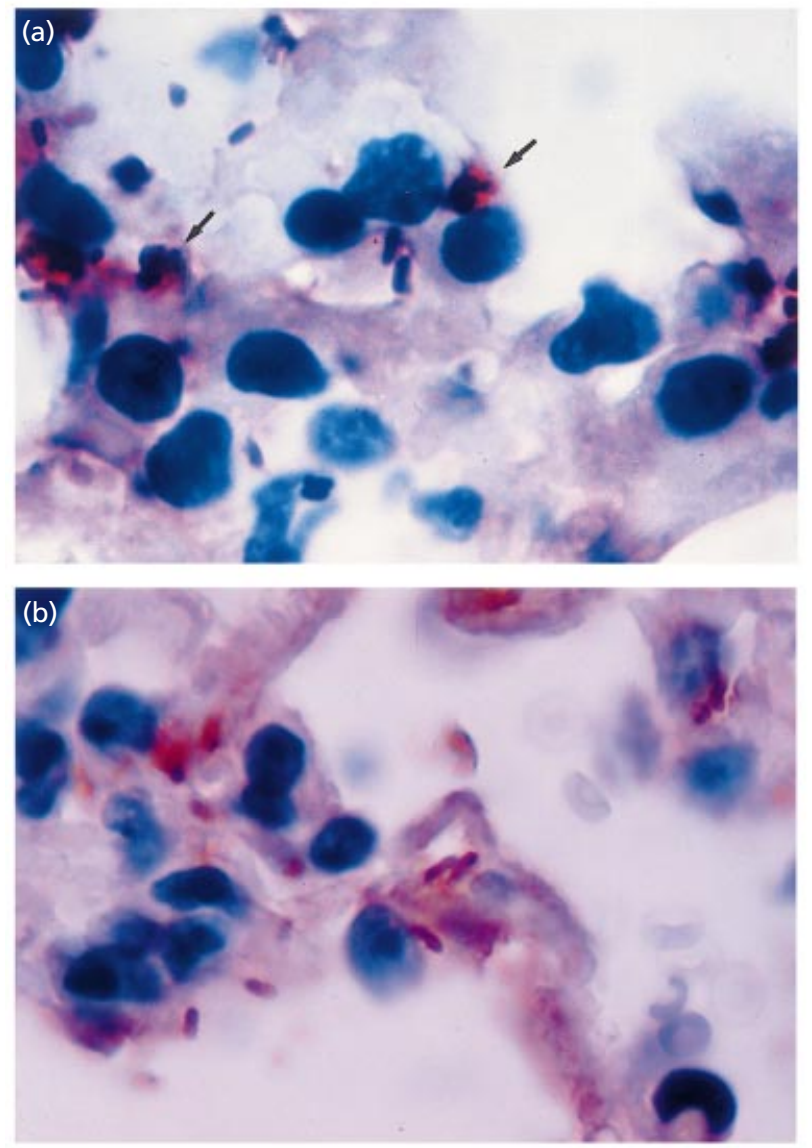

Fig. 2. In vivo adherence of $\mathrm{Cbl}^{+}$and $\mathrm{Cbl}^{-}$B. cepacia to murine respiratory tract epithelial cells. C57BL/6 mice were injected intratracheally with approximately $5 \times 10^{8}$ B. cepacia C5424 (a) and $\mathrm{C} 6433$ (b) in $50 \mu \mathrm{l}$ gel-HBSS and sacrificed by cervical dislocation $1 \mathrm{~h}$ after infection. Lung tissues were removed and immunoperoxidase-stained as described in Methods. Cbl ${ }^{+} \mathrm{C} 5424$ (a) shows clump formation (arrows), whereas $\mathrm{Cbl}^{-}$strain $\mathrm{C} 6433$ (b) predominantly exhibits single bacteria adhering.

(C5424), the inhibitory effect was largely abrogated: $6.9 \pm 0.5$ bound bacteria per washed cell without dextran; $1 \cdot 6 \pm 0 \cdot 1$ bound bacteria per unwashed cell with dextran (nominally $4000 \mathrm{Da}, 80 \mathrm{mg} \mathrm{ml}^{-1}$ ); $7 \cdot 4 \pm 1 \cdot 7$ bound bacteria per cell washed after dextran treatment. Similar results were seen if the bacteria were pretreated with dextran, then centrifuged once and resuspended in binding buffer before adding them to the epithelial cells. Under such conditions, the dextran-pretreated bacteria bound to epithelial cells as well as the PBS-pretreated bacteria $(5 \cdot 2 \pm 0 \cdot 4$ vs $6 \cdot 1 \pm 0 \cdot 7$ bound bacteria per cell).

\section{HPLC and MS}

Dextran, nominally $4000 \mathrm{Da}$, was actually a mixture of glucose and its oligomers, ranging in size from 1 to 19 glucose units with the majority of the sugars in the very low molecular mass range: 3-6 glucose units (527- 

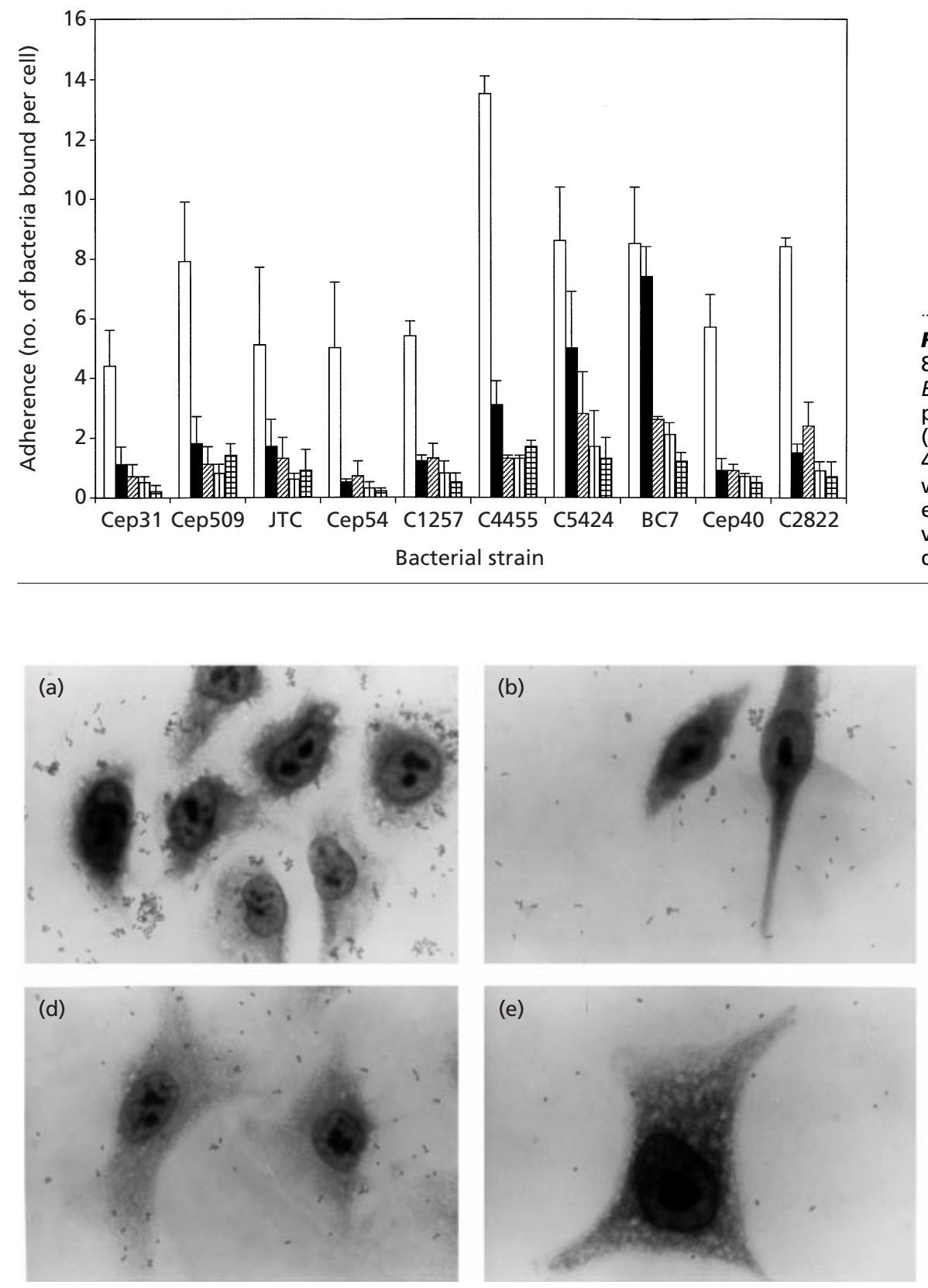

Fig. 3. The effect of dextran (20$80 \mathrm{mg} \mathrm{ml}^{-1}$ ) on binding of a number of B. cepacia strains to epithelial cells. A549 pneumocytes were pretreated with $0(\square), 20$ (四), 40 (四), 60 (四) or 80 (罡) mg nominally $4000 \mathrm{Da}$ dextran $\mathrm{ml}^{-1}$ and then $B$. cepacia was added. Cell-associated bacteria were enumerated visually. Results are mean values \pm SEM from three experiments, each done in duplicate.

Fig. 4. Adherence of $\mathrm{Cbl}^{+}$and $\mathrm{Cbl}^{-}$strains of $B$. cepacia to epithelial cells and inhibition by dextran. $\mathrm{Cbl}^{+} B$. cepacia strain C5424 (a, b, c) and Cbl ${ }^{-}$strain C6433 (d, e, f) were bound to A549 cells without any inhibitor (a, d) or in the presence of dextran (nominally $4000 \mathrm{Da}$ ) at $20 \mathrm{mg} \mathrm{ml}^{-1}(\mathrm{~b}, \mathrm{e})$ or $40 \mathrm{mg} \mathrm{ml}^{-1}(\mathrm{c}, \mathrm{f})$, then Giemsa-stained and enumerated visually as described in Methods.

$1013 \mathrm{Da})$ (Fig. 6). The expectation of a peak corresponding to 23 glucose units for nominally $4000 \mathrm{Da}$ dextran was not found by normal phase HPLC, nor by MS of underivatized dextran. Moreover, dextran, nominally $6000 \mathrm{Da}$, appeared very similar to dextran of $4000 \mathrm{Da}$, with a mean size of approximately 5 glucose units (828 Da). Dextran, nominally $10000 \mathrm{Da}$, was more uniform, but the mean molecular mass was low and far less than $10000 \mathrm{Da}$; the mean size detected was 12 glucose units (1962 Da). (c)

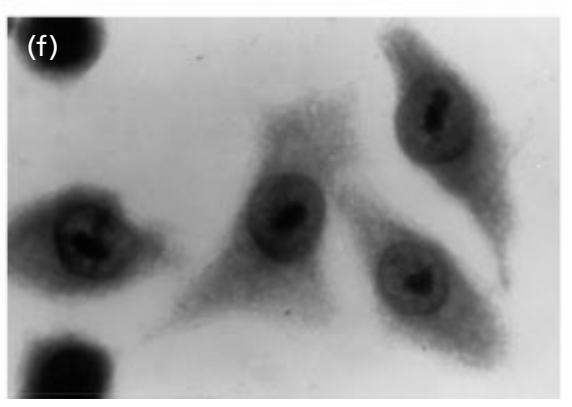




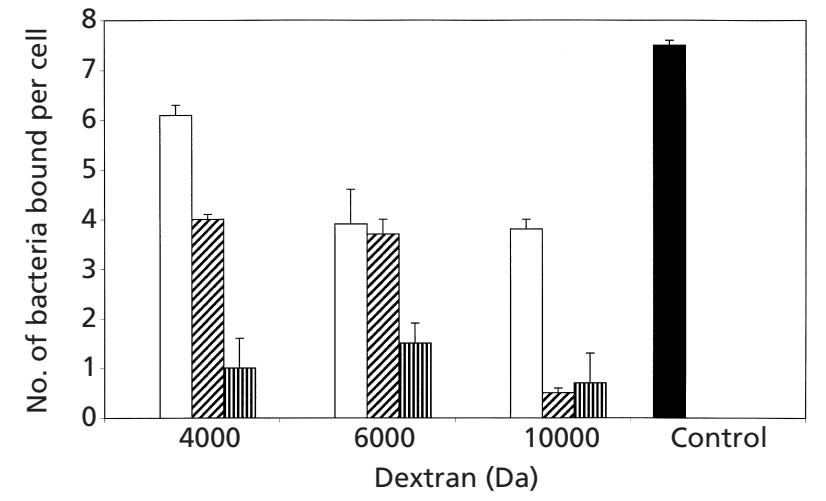

Fig. 5. The effect of dextrans of different nominal molecular mass on the binding of $B$. cepacia C5424 to epithelial cells. A549 pneumocytes were pretreated with $5(\square), 10(\square)$ or 20 (四) $\mathrm{mM}$ dextrans of different molecular mass or buffer control (西) and then B. cepacia C5424 was added. Cell-associated bacteria were enumerated visually. Results are mean values \pm SEM from three experiments, each done in duplicate. a molecular-mass-dependent inhibition of binding of C5424 to A549 cells with the isomaltotetraose exerting the greatest anti-adhesive effect (Table 2).

\section{DISCUSSION}

Our data indicate that dextran reduced the adherence of all strains of B. cepacia tested, including $\mathrm{Cbl}^{+}$and $\mathrm{Cbl}^{-}$ strains, to A549 immortalized pneumocytes. Adherence was suppressed by all molecular mass preparations tested, but when they were compared on an equal weight basis, the nominally $10000 \mathrm{Da}$ dextran was most inhibitory. A differential inhibitory effect was exerted by dextran of nominal molecular mass $4000 \mathrm{Da}^{\circ} \mathrm{Cbl}^{+} \mathrm{vs}$ $\mathrm{Cbl}^{-}$B. cepacia. These observations have important clinical implications: the $\mathrm{Cbl}^{+}$clone of $B$. cepacia appears to be highly contagious and pathogenic for $\mathrm{CF}$ patients so that any in vivo studies in the future attempting to prevent $B$. cepacia colonization in $\mathrm{CF}$ patients using dextran should utilize the optimal mol-

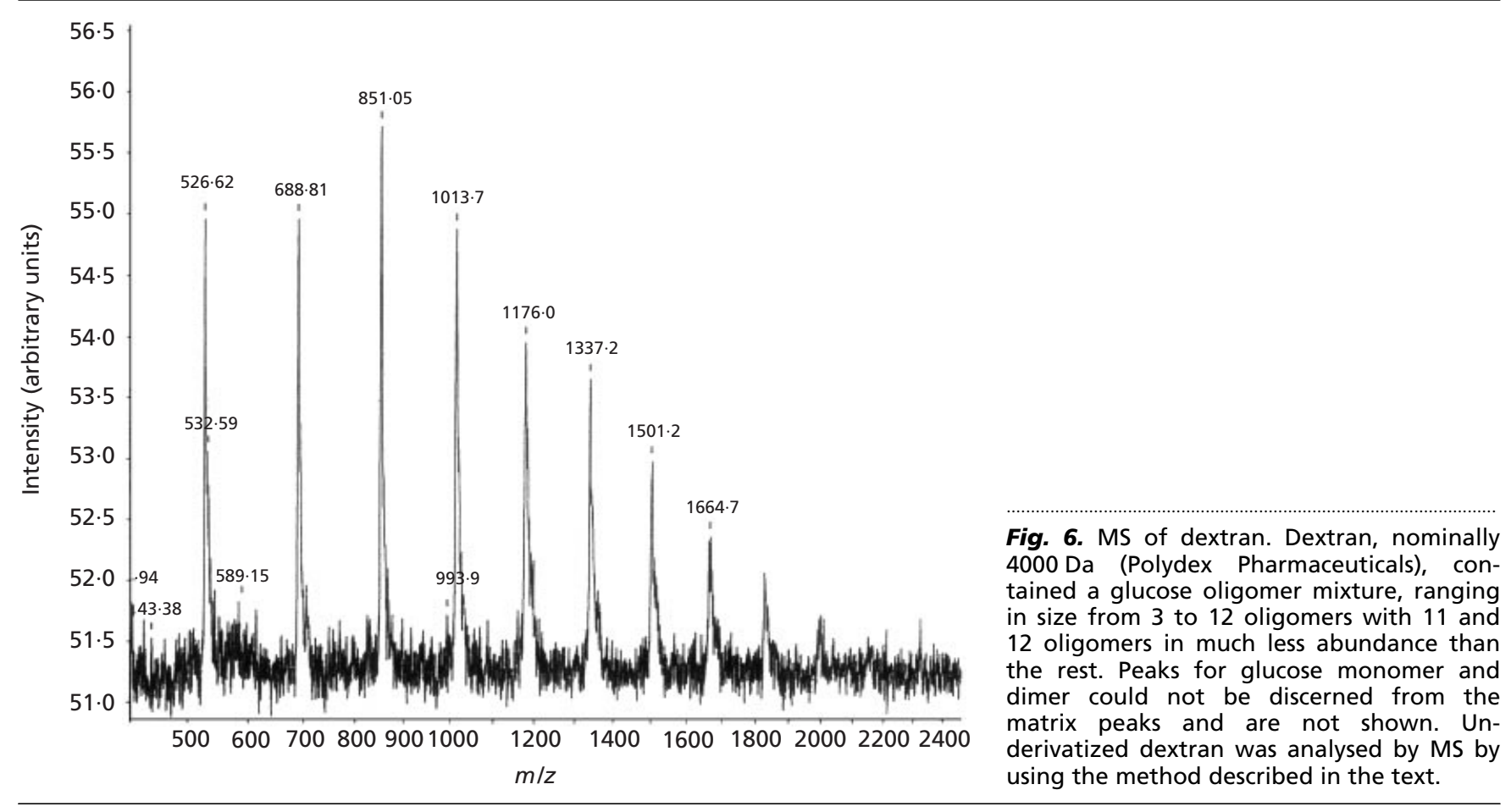

Table 2. The effect of isomaltose, isomaltotriose and isomaltotetraose on binding of B. cepacia strain C5424 to A549 epithelial cells

\begin{tabular}{|lcr|}
\hline Treatment* $^{*}$ & $\begin{array}{c}\text { Cell-associated bacteria } \\
(\text { mean } \pm \text { SEM) }\end{array}$ & Inhibition $(\%)$ \\
\hline Buffer control & $8 \cdot 2 \pm 2 \cdot 8$ & \\
Dextran (nominal molecular mass $4000 \mathrm{Da})$ & $1 \cdot 3 \pm 0 \cdot 1$ & $84 \cdot 1$ \\
Isomaltose & $8 \cdot 0 \pm 1 \cdot 2$ & $2 \cdot 4$ \\
Isomaltotriose & $6 \cdot 4 \pm 0 \cdot 5$ & $22 \cdot 0$ \\
Isomaltotetraose & $5 \cdot 2 \pm 0 \cdot 5$ & $36 \cdot 6$ \\
\hline
\end{tabular}

*20 mM, according to the nominal molecular masses of the sugars tested. 
ecular mass of dextran. If dextran of nominal molecular mass $4000 \mathrm{Da}$ is used, a concentration of $\geqslant 40 \mathrm{mg} \mathrm{ml}^{-1}$ or more would have to be applied. A concern with this concentration of dextran is that the administration of such a large dose to the airway may cause osmotic injury to the epithelial cells; however, recent murine studies (Bryan et al., 1999) demonstrated that aerosol delivery of high dose nominally $4000 \mathrm{Da}$ dextran did not result in any histopathology.

The authentic molecular masses of dextrans utilized in this study were at variance with those reported by the manufacturer. The concentration of dextran preparations used in our previous studies were based on the manufacturer's quoted molecular mass (Barghouthi et al., 1996; Bryan et al., 1999). The mean molecular masses of dextrans used, as determined by gel filtration and MS, were approximately 10 -fold lower than that indicated. Thus the reported apparent molarities must be adjusted according to the authentic molecular mass determined. It is not practical to determine the molecular mass of all dextrans used in studies such as these (Barghouthi et al., 1996; Bryan et al., 1999), but our observations should provide a note of caution in interpreting results.

All data from the present as well as previous studies (Barghouthi et al., 1996) support the conclusion that dextran blocks the adherence of $B$. cepacia in a nonspecific fashion; that is, it does not interfere with a single type of receptor-ligand interaction. Observations in favour of this conclusion are: the inhibitory effect was readily reversible; oligosaccharides composed of 2-4 glucose units with the same $\alpha-1,6$ linkage were only minimally inhibitory; dextran did not bind specifically to either P. aeruginosa or epithelial cells (Barghouthi et al., 1996); and dextran blocked attachment of other respiratory tract pathogens (Staphylococcus aureus, group A streptococcus and Haemophilus influenzae) as well (Barghouthi et al., 1996).

The mechanism by which dextran inhibits adhesion of bacteria to epithelial cells remains incompletely understood. However, it has been recognized for years that dextran has pervasive effects on cell-cell interactions. For instance, it enhances erythrocyte clumping and is used as an agent for facilitating sedimentation in vitro. Furthermore, it inhibits platelet adhesiveness and has anticoagulant activity (Cronberg et al., 1966). Dextran could have exerted its inhibitory effect by coating both the epithelial cells and the bacteria. One possible target for this antiadhesive effect was the Cbl pilus on the bacteria.

After their discovery in 1995, Cbl pili have been identified as one of the adhesins of a specific epidemic $B$. cepacia clone (Goldstein et al., 1995; Sajjan et al., 1995). Sajjan et al. (2000) recently found that cytokeratin 13 (CK13) may be the target for the binding of cablepiliated B. cepacia; however, the expression of CK13 in normal human bronchial epithelial cells is low. In the current study, we demonstrated that epidemic B. cepacia isolates, irrespective of cable piliation, are capable of attaching both in vitro and in vivo to respiratory tract epithelial cells. These data suggest that the $\mathrm{Cbl}$ pilus is not the only factor required for adherence of epidemic B. cepacia strains to respiratory tract epithelial cells. Furthermore, we found that the $\mathrm{Cbl}^{+}$strains of B. cepacia formed clumps when they bound to A549 pneumocytes, whereas the $\mathrm{Cbl}^{-}$strains bound as single bacteria. It was also the case when B. cepacia were bound to murine respiratory tract epithelial cells in vivo. A previous study indicated that most $\mathrm{Cbl}^{+}$B. cepacia isolates from CF patients exhibited a rough morphotype that were subject to autoagglutination (Butler et al., 1994). This rough LPS morphotype could contribute to clump formation when bacteria bind to epithelial cells. The observations of this study strongly support the speculation that the $\mathrm{Cbl}^{+}$strains are able to co-aggregate via tangling with similar fibres from neighbouring bacteria, thus enhancing the attachment and the survival of the bacterial microcolonies on the respiratory tract epithelial cells. This autoaggregation may play a role in enhancing the virulence of $B$. cepacia in the lung of patients with CF. As shown in this study, dextran can effectively inhibit the bacterial binding as well as change the specific binding pattern associated with the $\mathrm{Cbl}$ pili.

Dextran has several features that make it an attractive candidate therapeutic agent for preventing respiratory tract infections in patients with CF. It is inexpensive, non-toxic and, most importantly, of low viscosity, even at a high concentration. It therefore can be aerosolized readily (Bryan et al., 1999; Finlay et al., 2000). The ability of aerosolized dextran to protect mice from pneumonia due to $P$. aeruginosa has been documented (Bryan et al., 1999). Our data further confirmed the in vitro effect of dextran in another important CF pathogen, B. cepacia. Other studies have demonstrated that dextran improves mucociliary clearance of CF sputum as monitored using a frog palate mucociliary transportability assay (Feng et al., 1996). The combined effect on sputum rheology and inhibitory effect on bacterial adherence together suggest that dextran delivered by aerosol may be useful in patients with CF to prevent colonization and infection with $P$. aeruginosa and B. cepacia.

\section{ACKNOWLEDGEMENTS}

The authors gratefully acknowledge the assistance of Geoffrey Guile from the Edward Jenner Institute for Vaccine Research in the separation and analysis of dextran preparations. This work was supported by Canadian Cystic Fibrosis Foundation SPARXI Programme and the Canadian Bacterial Diseases Network (both to D.P.S.).

\section{REFERENCES}

Ashford, D., Dwek, P. A., Welply, J. K., Amatayakul, S., Homans, S. W., Lis, H., Taylor, G. N., Sharon, N. \& Rademacher, T. W. (1987). The beta-2-D-xylose and alpha-1-3-L-fucose substituted $N$-linked oligosaccharides from Erythrina cristagalli lectin. Isolation, characterization and comparison with other legume lectins. Eur J Biochem 166, 311-320. 
Barghouthi, S., Guerdoud, L. M. \& Speert, D. P. (1996). Inhibition by dextran of Pseudomonas aeruginosa adherence to epithelial cells. Am J Respir Crit Care Med 154, 1788-1793.

Bigge, J. C., Patel, T. P., Bruce, J. A., Goulding, P. N., Charles, S. M. \& Parekh, R. B. (1995). Nonselective and efficient fluorescent labeling of glycans using 2 -amino benzamide and anthranilic acid. Anal Biochem 230, 229-238.

Bryan, R., Feldman, M., Jawetz, S. C., Rajan, S., DiMango, E., Tang, H. B., Scheffler, L., Speert, D. P. \& Prince, A. (1999). The effects of aerosolized dextran in a mouse model of Pseudomonas aeruginosa pulmonary infection. J Infect Dis 179, 1449-1458.

Burns, J. L., Jonas, M., Chi, E. Y., Clark, D. A., Berger, A. \& Griffith, A. (1996). Invasion of respiratory epithelial cells by Burkholderia (Pseudomonas) cepacia. Infect Immun 64, 4054-4059.

Butler, S. L., Nelson, J. W., Poxton, I. R. \& Govan, J. R. W. (1994). Serum sensitivity of Burkholderia (Pseudomonas) cepacia isolates from patients with cystic fibrosis. FEMS Immunol Med Microbiol 8, 285-292.

Canadian cystic fibrosis foundation medical/scientific advisory committee (1993). Epidemiology of Pseudomonas cepacia in cystic fibrosis. Can J Infect Dis 4, 163-164.

Cronberg, S., Robertson, B., Nilsson, I. M. \& Nilehn, J. E. (1966). Suppressive effect of dextran on platelet adhesiveness. Thromb Diath Haemorrh 16, 384-394.

Feng, W., Garrett, H., Speert, D. P. \& King, M. (1996). Improved clearability of cystic fibrosis sputum with dextran treatment in vitro. Am J Respir Crit Care Med 154, 1788-1793.

Finlay, W. H., Lange, C. F., King, M. \& Speert, D. P. (2000). Lung delivery of aerosolized dextran. Am J Respir Crit Care Med 16, 91-97.

Goldstein, R., Sun, L., Jiang, R. Z., Sajjan, U. S., Forstner, J. F. \& Campbell, C. (1995). Structurally variant classes of pilus appendage fibers coexpressed from Burkholderia (Pseudomonas) cepacia. J Bacteriol 177, 1039-1052.

Govan, J. R., Hughes, J. E. \& Vandamme, P. (1996). Burkholderia cepacia: medical, taxonomic, and ecological issues. J Med Microbiol 45, 395-407.

Guile, G. R., Rudd, P. M., Wing, D. R., Prime, S. B. \& Dwek, R. A. (1996). A rapid high-resolution high-performance liquid chromatographic method for separating glycan mixtures and analyzing oligosaccharide profiles. Ann Biochem 240, 210-226.

Isles, A., MacLusky, I., Corey, M., Gold, R., Prober, C., Fleming, P. \& Levison, H. (1984). Pseudomonas cepacia infection in cystic fibrosis: an emerging problem. J Pediatr 104, 206-210.

Kuehn, M., Lent, K., Haas, J., Hagenzicker, J., Cervin, M. \& Smith, A. L. (1992). Fimbriation of Pseudomonas cepacia. Infect Immun 60, 2002-2007.
Kuster, B., Wheeler, S. F., Hunter, A. P., Dwek, R. A. \& Harvey, D. J. (1997). Sequencing of $N$-linked oligosaccharides directly from protein gels: in-gel deglycosylation followed by matrixassisted laser desorption/ionization mass spectrometry and normal-phase high-performance liquid chromatography. Ann Biochem 250, 82-101.

Mahenthiralingam, E., Campbell, M. E., Henry, D. A. \& Speert, D. P. (1996). Epidemiology of Burkholderia cepacia infection in patients with cystic fibrosis: analysis by randomly amplified polymorphic DNA fingerprinting. J Clin Microbiol 34, 2914-2920.

Mahenthiralingam, E., Simpson, D. A. \& Speert, D. P. (1997). Identification and characterization of a novel DNA marker associated with epidemic Burkholderia cepacia strains recovered from patients with cystic fibrosis. J Clin Microbiol 35, 808-816.

Saini, L. S., Galsworthy, S. B., John, M. A. \& Valvano, M. A. (1999). Intracellular survival of Burkholderia cepacia complex isolates in the presence of macrophage cell activation. Microbiology 145, 3465-3475.

Sajjan, U. S. \& Forstner, J. F. (1992). Identification of the mucinbinding adhesin of Pseudomonas cepacia isolates from patients with cystic fibrosis. Infect Immun 60, 1434-1440.

Sajjan, U. S. \& Forstner, J. F. (1993). Role of the 22-kilodalton pilin protein in binding of Pseudomonas cepacia to buccal epithelial cells. Infect Immun 61, 3157-3163.

Sajjan, U. S., Sun, L., Goldstein, R. \& Forstner, J. F. (1995). Cable (Cbl) type II pili of cystic fibrosis-associated Burkholderia (Pseudomonas) cepacia: nucleotide sequence of the cblA major subunit pilin gene and novel morphology of the assembled appendage fibers. J Bacteriol 177, 1030-1038.

Sajjan, U. S., Sylvester, F. A. \& Forstner, J. F. (2000). Cablepiliated Burkholderia cepacia binds to cytokeratin 13 of epithelial cells. Infect Immun 68, 1787-1795.

Snell, G. I., de Hoyos, A., Krajden, M., Winton, T. \& Maurer, J. R. (1993). Pseudomonas cepacia in lung transplant recipients with cystic fibrosis. Chest 103, 466-471.

Speert, D. P. (1989). Prevention of severe lower respiratory infections in patients with cystic fibrosis. Semin Respir Infect 4, 266-271.

Tablan, O. C., Chobra, T. L., Schidlow, D. V. \& 7 other authors. (1985). Pseudomonas cepacia colonization in patients with cystic fibrosis: risk factors and clinical outcome. J Pediatr 107, 382-387.

Vandamme, P., Holmes, B., Vancanneyt, M. \& 8 other authors. (1997). Occurrence of multiple genomovars of Burkholderia cepacia in cystic fibrosis patients and proposal of Burkholderia multivorans sp. nov. Int J Syst Bacteriol 47, 1188-1200.

Received 12 April 2001; revised 19 June 2001; accepted 27 June 2001. 